\title{
Impact of broom, Cytisus scoparius (Fabaceae), in naturally treeless sub-alpine frost-hollow vegetation communities at the Barrington Tops, south-eastern Australia
}

\author{
John R. Hosking ${ }^{1,3}$, Mellesa Schroder ${ }^{2}$ and Bruce McCorkell ${ }^{1}$ \\ ${ }^{1}$ Tamworth Agricultural Institute, NSW Department of Primary Industries, 4 Marsden Park Road, Calala, NSW 2340 AUSTRALIA. \\ email bruce.mccorkell@dpi.nsw.gov.au \\ ${ }^{2}$ NSW Office of Environment and Heritage, National Parks and Wildlife Service, \\ corner of Kosciusko Way and Thredbo Terrace, Jindabyne, NSW 2627 AUSTRALIA. \\ emailmel.schroder@environment.nsw.gov.au \\ ${ }^{3}$ current address: NCW Beadle Herbarium, University of New England, Armidale, NSW 2351 AUSTRALIA. \\ email jandjhosking@optusnet.com.au
}

\begin{abstract}
The exotic shrub Cytisus scoparius (L.) Link (family Fabaceae), known as broom, is having a major impact on native vegetation in naturally treeless sub-alpine frost-hollow areas (c. 32 $01^{\prime} 37^{\prime \prime} \mathrm{S}, 151^{\circ} 26^{\prime} 12^{\prime \prime}$ E', $1440 \mathrm{~m}$ elevation) at the Barrington Tops, New South Wales, in south-eastern Australia. This vegetation is of limited extent and has significant biogeographical and ecological importance. Nine paired $10 \mathrm{~m}$ line transects were compared, with one of the pair in areas of almost 100\% Cytisus scoparius and the other in adjacent areas without Cytisus scoparius. Results were compared with species recorded from this area in the 1930s. There are obvious differences in native vegetation in areas with and without Cytisus scoparius. On average there were 5.1 (range 2-10) species per $10 \mathrm{~m}$ in areas of almost 100\% Cytisus scoparius cover and $17.0(12-25)$ species per $10 \mathrm{~m}$ in areas adjacent to infested areas but without Cytisus scoparius. Other than Cytisus scoparius, the area surveyed had little in the way of exotic species and these were only present at low densities. Native species present in 2008 are similar to those recorded in the 1930s; there were no records of Cytisus scoparius in the area in the 1930s. The study suggests that control of Cytisus scoparius in naturally treeless areas at the Barrington Tops should be a priority to prevent a decline in the distribution and abundance of many plant species, many of which only occur in treeless areas of the Barrington Tops.
\end{abstract}

Keywords: Cytisus scoparius; broom; weed impact; vegetation change; Barrington Tops; frost-hollow vegetation.

Cunninghamia 13: 337-351.

doi: 10.7751 cunninghamia2013.010 


\section{Introduction}

The exotic shrub Cytisus scoparius (L.) Link, (family Fabaceae) known as broom, is native to Europe but has naturalised and is a weed in many countries around the world including Australia, New Zealand, U.S.A., Canada, India, Iran, Japan, South Africa, Argentina and Chile (Parsons \& Cuthbertson 1992, Gómez-Sosa in Zuloaga \& Morrone 1999, Arroyo et al. in Mooney \& Hobbs 2000, Ohashi in Iwatsuki et al. 2001). A summary of information on Cytisus scoparius in Australia until 1998 can be found in Hosking et al. (1998). Since that time there have been a number of other published studies on Cytisus scoparius in Australia (Fogarty \& Facelli
1999, Downey \& Smith 2000, Sheppard \& Hosking 2000, Sheppard et al. 2002, Paynter et al. 2003, Wearne \& Morgan 2004, 2006, Stokes et al. 2006). In New South Wales the invasion and establishment of Cytisus scoparius has been listed as a key threatening process in schedule 3 of the NSW Threatened Species Conservation Act 1995 (DECC 2008).

The Barrington Tops sub-alpine plateau ranging in elevation from $1300 \mathrm{~m}$ to $1586 \mathrm{~m}$ is situated in south-eastern Australia, on the northern side of the Hunter Valley, New South Wales (Figure 1). Vegetation on the sub-alpine plateau has been geographically isolated from other high altitude eastern Australian areas and has many endemic species.
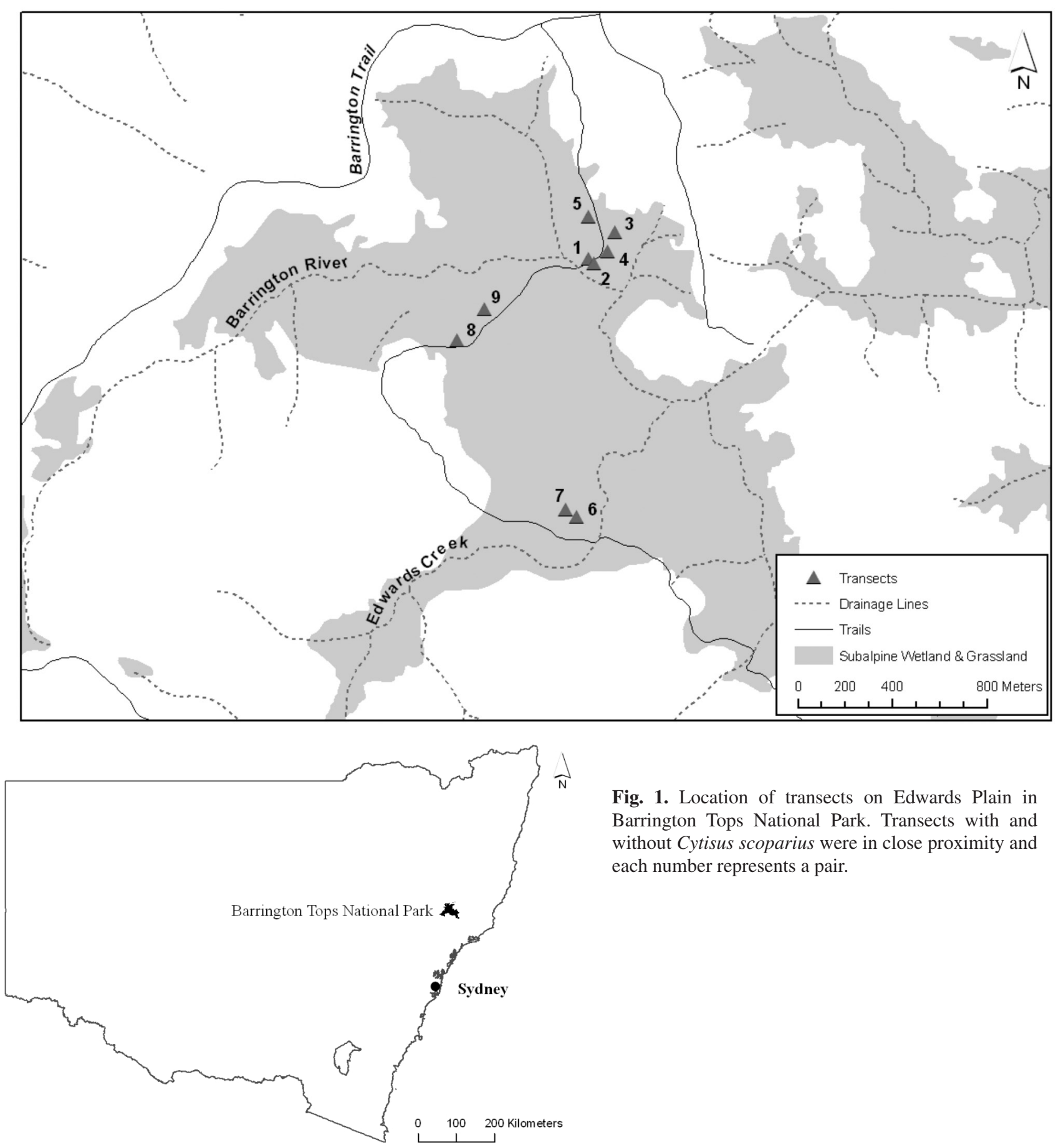

Fig. 1. Location of transects on Edwards Plain in Barrington Tops National Park. Transects with and without Cytisus scoparius were in close proximity and each number represents a pair. 
On the Barrington Tops an extensive Cytisus scoparius infestation is displacing native vegetation. The species is believed to have been grown on the property 'Tomalla' in the 1840s and was not observed far south of 'Tomalla' before the late 1940s (Waterhouse 1988). According to references in Waterhouse (1988) expansion in range and density of Cytisus scoparius seems to have taken place since 1969 when the southern end of the plateau became a National Park and seasonal grazing and associated burning ceased. It now occupies over 10000 ha of sub-alpine plateau on the Barrington Tops and is continuing to spread (OEH 2011). Management of Cytisus scoparius has been undertaken since the 1970 s with varying levels of success (Schroder \& Howard 2000, Odom et al. 2003).

The establishment and expansion of Cytisus scoparius in the treeless vegetation community has occurred over the past twenty years with very little understanding of the impacts on native vegetation. Waterhouse (1988) discussed the impact of Cytisus scoparius on trees but did not detail the impact on other species. Our work is the first study covering the impact of Cytisus scoparius on naturally treeless areas of the Barrington Tops. The only previously published information on vegetation in grasslands adjoining swamps and below woodlands on the Barrington Tops, the area covered by this study, is in the pioneering ecological work of Fraser \& Vickery (1939) though many of the species names that they use have subsequently changed. Heinrich \& Dowling (2000) focussed on known rare and threatened plant species in the montane wetlands and peatlands that occur below the naturally treeless vegetation communities. The montane wetlands and peatlands are listed as an Endangered Ecological Community under the NSW Threatened Species Conservation Act (1995).

Since the mid 1980s management of Cytisus scoparius on the Barrington Tops has focussed on containment including control along tracks and trails and preventing its dispersal into non-infected catchments. Cytisus scoparius control has been undertaken in the montane wetlands that adjoin the treeless vegetation. Following Heinrich \& Dowling's (2000) survey work in 1998 control of Cytisus scoparius within the wetlands and adjoining vegetation, including areas of naturally treeless sub-alpine frost-hollow vegetation, was expanded (Schroder \& Howard 2000, DECC 2010). The objective of this study was to determine the impact of Cytisus scoparius on the native vegetation of naturally treeless subalpine frost-hollow vegetation.

\section{Methods}

\section{Study area}

The climate on the Barrington Tops plateau has sub-alpine influences with rainfall ranging from $1000 \mathrm{~mm} / \mathrm{yr}$ in the north west to about $2000 \mathrm{~mm} / \mathrm{yr}$ in the south east. Average temperatures on the plateau above $1300 \mathrm{~m}$ range from -2 to $9^{\circ} \mathrm{C}$ in July to 9 to $23^{\circ} \mathrm{C}$ in January (CMPS \& F Environmental 1995). Snowfalls occur in winter above
$1100 \mathrm{~m}$ as a result of cold fronts. Summers can be warm but temperatures above $30^{\circ} \mathrm{C}$ are rare.

The study area was on Edwards Plain (c. $32^{\circ} 01^{\prime} 37^{\prime \prime} \mathrm{S}, 151^{\circ}$ 26' 12" E) about $1440 \mathrm{~m}$ above sea level, at the southern end of the Barrington Tops plateau in Barrington Tops National Park (Figure 1). Soil on the plain is a brown humic loam with no substrate evident. The study area is one of a number of low lying areas at higher elevation where cold air ponding occurs. It is a naturally treeless plain between woodland and swampy areas alongside the Barrington River and its tributaries. In recent times this area has been increasingly invaded by Cytisus scoparius; mapping of this species in 1989 and 1999 demonstrated a gradual invasion into the treeless vegetation areas (Odom et al. 2003, DECC 2010).

\section{Vegetation sampling}

This study was undertaken in February 2008. Previously twenty $20 \mathrm{~m}$ long line transects had been surveyed from 2003 in different types of Cytisus scoparius invaded vegetation on the Barrington Tops (Hosking \& Shroder unpubl). Impacts of Cytisus scoparius shown in that study varied considerably between different vegetation communities and the present study was devised to examine Cytisus scoparius impact in the area where impact appeared to be greatest.

Line transects were used in this study (and studies that began in 2003) as this was believed to give more accurate information on ground cover than use of other vegetation sampling techniques and also prevented trampling of native vegetation which may have impeded identification of smaller plants. Eighteen transects were used, each $10 \mathrm{~m}$ long, 9 in Cytisus scoparius infested areas, and 9 in adjacent areas that had not been invaded by Cytisus scoparius. The first half of the first transect that began in 2003 corresponds to the first Cytisus scoparius transect of this study. Centimetres of line cover by each species was determined for each metre and converted to a percentage cover for each transect. Cytisus scoparius in this area grows to around $2 \mathrm{~m}$ high and forms a dense canopy. For each vertical projection of the edge of the tape each species was recorded only once so that species do not exceed 100 percent ground cover. As species overlapped in many areas cover for all species in each transect could be greater than 100 percent.

Comparison of Cytisus scoparius infested transects with those from sites without this species was conducted with nonmetric multi-dimensional scaling (NMDS) (Fasham 1977, Prentice 1977), a multivariate analysis technique that, in this case, examined the complexity of species composition along each of the 18 transects. The complexity of these plant communities was based on the presence, and relative abundance, of each of 49 identified species, excluding Cytisus scoparius, within each metre of each of the 18 transects examined.

In December 2007 the Cytisus scoparius infested areas had been sprayed with triclopyr (Garlon® 600 at $170 \mathrm{ml}$ per 100 litres). This is not thought to have influenced the species present, as data from 2003 to 2007 for the first Cytisus scoparius infested transect showed few species. This transect, nor any 
other transect in the 2008 study, showed evidence of ever being treated with herbicide prior to December 2007. Where transect cover with dead and dying Cytisus scoparius plants was continuous, transect cover was considered to be $100 \%$ though as a vertical projection this would have been slightly less. Determination of actual cover in such areas would have been extremely difficult and would not have been accurate. As a result of spraying Cytisus scoparius leaves had largely been shed by dying plants and this probably increased density of Poa sieberiana through increased light reaching plants below the Cytisus scoparius canopy. There were no remains of sprayed plants other than Cytisus scoparius evident in sprayed areas despite it being only 2 months after spraying. The age of Cytisus scoparius plants with large stem diameters in close proximity to transects was assessed by counting yearly growth rings of three randomly selected shrubs for each Cytisus scoparius infested transect.

Plant identification is based on years of plant collecting, mostly by J.R. Hosking, at the Barrington Tops. Names used here follow those used in PlantNET (http://plantnet. rbgsyd.nsw.gov.au/). Herbarium codes follow Holmgren et al. (1990). Vouchers of all the species listed are held at the National Herbarium of New South Wales (coded NSW) and in most cases also at the Australian National Herbarium (CANB), the National Herbarium of Victoria (MEL) and the herbarium of the University of New England (NE).

\section{Species composition in this area in the 1930 s}

Comparisons are made with species listed for this area by Fraser \& Vickery (1939) who compiled lists of species that occurred in various areas in the upper Williams River and the Barrington Tops districts. Their lists do not appear to be based on transect data but appear to be the result of observations made on numerous trips to the area. This information is used to compare differences and similarities in species present in the 1930s and at the time of this study. There have been considerable advances in plant taxonomy since 1939 and fortunately Fraser \& Vickery collected specimens (now lodged at NSW and the University of Sydney (SYD) that enabled comparisons to be made between the two studies. In some cases it was not possible to relate the name used by Fraser \& Vickery to those of this study as no voucher specimens for collections made from the area before 1939 are present at NSW and SYD, and the species that they listed is not known to occur in the area.

\section{Data analysis}

Transect data, consisting of lengths of transect covered by identified plant species, were converted to an ordinal format based on the relative abundance of each species. The presence of Cytisus scoparius, because of its dominance in

Fig. 2. Tetrarrhenia turfosa, a grass only recorded from treeless areas and rarely found in areas impacted by Cytisus scoparius at the Barrington Tops.

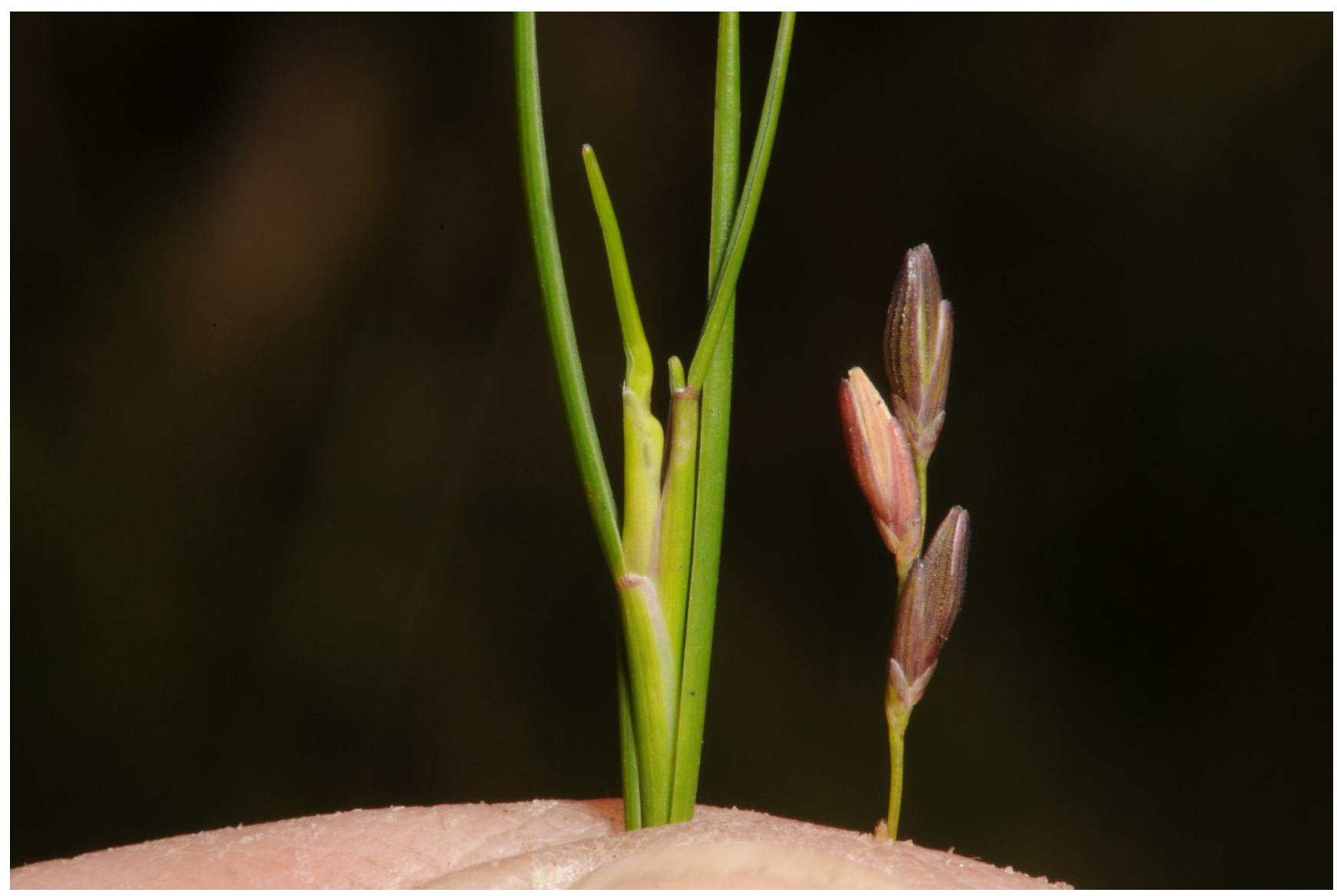


Table 1. Plant species cover in February 2008 in open plains transects without Cytisus scoparius on Edwards Plain, Barrington Tops National Park. Collection numbers are given for species without a name currently.

Genus / species (family (subfamily)) * = naturalised

Poa sieberiana (Poaceae)

Empodisma minus (Restionaceae)

Tetrarrhena turfosa (Poaceae)

Carex sp. (JRHosking 2585 et al.) (Cyperaceae)

Oreomyrrhis eriopoda (Apiaceae)

Scaevola hookeri (Goodeniaceae)

Pultenaea fasciculata (Fabaceae (Faboideae))

Epacris breviflora (Ericaceae (Epacridoideae))

Hakea microcarpa (Proteaceae)

Erigeron bellidioides (Asteraceae)

Leucopogon pilifer (Ericaceae (Epacridoideae))

Coronidium scorpioides (Asteraceae)

Rytidosperma penicillatum (Poaceae)

Luzula modesta (Juncaceae)

Luzula densiflora \&/or L. meridionalis (Juncaceae)

Wahlenbergia ceracea (Campanulaceae (Campanuloideae))

Craspedia variabilis (Asteraceae)

Mitrasacme serpyllifolia (Loganiaceae)

Hydrocotyle peduncularis (Araliaceae)

Carex sp. (JRHosking 2873) (Cyperaceae)

Gentianella barringtonensis (Gentianaceae)

Euchiton involucratus (Asteraceae)

Ranunculus lappaceus (Ranunculaceae)

*Hypochaeris radicata (Asteraceae)

Euphrasia ciliolata (Orobanchaceae)

Xerochrysum bracteata with yellow involucral bracts

(JRHosking 2586 et al.) (Asteraceae)

Microlaena stipoides var. stipoides (Poaceae)

Arthropodium milleflorum (Asparagaceae (Lomandroideae)) $0.5 \quad 0.2$

Deyeuxia gunniana (Poaceae)

Dichelachne inaequiglumis (Poaceae)

Solenogyne gunnii (Asteraceae)

Acaena novae-zelandiae (Rosaceae (Rosoideae))

Scleranthus sp. (JRHosking 2489) (Caryophyllaceae)

Viola betonicifolia subsp. betonicifolia (Violaceae)

Dichondra repens (Convolvulaceae)

Hypoxis hygrometrica var. hygrometrica (Hypoxidaceae)

Xerochrysum bracteata with white involucral bracts

(JRHosking 3202) (Asteraceae)

Unidentified Monocotyledon

Viola fuscoviolacea (Violaceae)

Ajuga sp. (JRHosking 2314 \& JMBakonji) (Lamiaceae)

*Cerastium vulgare (Caryophyllaceae)

Gonocarpus humilis (Haloragaceae)

Leucopogon fraseri (Ericaceae (Epacridoideae))

Pterostylis sp. (Orchidaceae)

Rytidosperma laeve (Poaceae)

*Trifolium repens (Fabaceae (Faboideae)

Velleia montana (Goodeniaceae)

Number of species

Groundcover for all species

Groundcover for species other than Poa sieberiana

0.5

0.4
0.2

0.9

0.1

0.1

\section{Cover in transects $(\%)$}

Total Cover

$\begin{array}{llllllllll}1 & 2 & 3 & 4 & 5 & 6 & 7 & 8 & 9\end{array}$

(\%)

$\begin{array}{llll}89 & 92 & 91 & 91 \\ & & 5 & 49.5 \\ & 1.1 & 20.3 & \\ 3 & 2.9 & 0.3 & 1.6 \\ 7.2 & 4.7 & 1.1 & 0.7 \\ & & & 1.9\end{array}$

$\begin{array}{lllll}69.5 & 54 & 63.7 & 100 & 86\end{array}$

81.80

$\begin{array}{lllll}48 & 65.5 & 39.7 & 0.6 & 23.14\end{array}$

$\begin{array}{llllll}68 & 1.3 & 17.9 & 0.2 & 3.8 & 12.51\end{array}$

$\begin{array}{llllll}2.4 & 3.1 & 2.7 & 1.9 & 4.8 & 2.52\end{array}$

1.9

$\begin{array}{lll}0.9 & 3.3 & 1.7\end{array}$

2.18

$15.5 \quad 1.93$

1.38

1.36

1.27

1.20

$\begin{array}{llllllllll}2.9 & 1.3 & 0.1 & 1.7 & 0.2 & 2.4 & 1.4 & & 0.1 & 1.12\end{array}$

$\begin{array}{llll}3.3 & 2.4 & 0.2 & 1.7\end{array}$

$\begin{array}{lll}6.8 & 0.1 & 0.2\end{array}$

$\begin{array}{llll}0.4 & 0.3 & 0.1 & 0.4 \\ 0.6 & 0.8\end{array}$

$\begin{array}{llll}0.7 & 0.5 & 3.3 & 1.1\end{array}$

$0.1 \quad 0.5$

0.1

$\begin{array}{ll} & 0.7 \\ 0.4 & 0.1\end{array}$

$\begin{array}{ll}0.4 & 0.1\end{array}$

0.3
0.4

0.1

0.1

$0.7 \quad 0.1$

0.3

0.1

0.2

0.7

0.96

$\begin{array}{ll}2 & 2.1\end{array}$

2.2

$\begin{array}{lll}0.7 & 1.1 & 0.9\end{array}$

1.3

(1)

0.89

0.79

0.76

$\begin{array}{ll}0.3 & 0.5\end{array}$

$0.2 \quad 4$

$\begin{array}{lll}0.2 & 0.1 & \\ 0.3 & 1 & 0.1 \\ 0.9 & 0.2 & 0.2\end{array}$

0.71
0.51

0.33

$\begin{array}{llllll}0.3 & 1 & 0.1 & & 0.1 & 0.27 \\ 0.9 & 0.2 & 0.2 & 0.3 & & 0.23\end{array}$

$\begin{array}{lll}1 & 0.2 & 0.18\end{array}$

$\begin{array}{ll}1.4 & 0.17\end{array}$

$0.5 \quad 0.16$

$\begin{array}{lll}0.2 & 0.8 & 0.12\end{array}$

$0.1 \quad 0.11$

$\begin{array}{lll}0.2 & 0.1 \quad 0.1\end{array}$

0.09

0.08

0.5

0.3

0.08

0.06

$0.5 \quad 0.06$

$\begin{array}{ll}0.4 & 0.04\end{array}$

$\begin{array}{lll}0.1 & 0.3 & 0.04\end{array}$

0.4

$0.3 \quad 0.03$

0.1

$0.2 \quad 0.03$

0.3

0.03

0.3

0.03

$0.2 \quad 0.02$

$0.1 \quad 0.01$

$\begin{array}{ll}0.1 & 0.01\end{array}$

0.1

0.1

0.0

0.01

0.01

0.01

0.01

0.01 
transects where it was present, was ignored, allowing greater emphasis to be placed on the other species present.

A Euclidean distance matrix, created from the ordinal transect data with primary treatment of ties, was used to describe the similarities between transects based on the relative abundance of identified vegetation species. There is no transformation of these ordinal data - converting categorical data to a metric scale is not recommended.

\section{Results}

\section{Impact of Cytisus scoparius on native species}

Our results show major differences in species richness and species groundcover in transects with and without Cytisus scoparius (Figures 3 and 4). Species richness in line transects with almost $100 \%$ Cytisus scoparius cover was 5.1 species per $10 \mathrm{~m}$ (range 2-10) while in adjacent uninfested transects species richness was 17.0 species per $10 \mathrm{~m}$ (range 12-25) (Figure 3). Groundcover of species other than Poa sieberiana was also severely impacted with on average $4 \%$ ground cover (range 0-19\%) in areas with close to $100 \%$ Cytisus scoparius cover. In adjacent uninfested areas groundcover was $55 \%$ (range 19-121\%) (Figure 4).

A total of 44 native species (and 3 exotics) were recorded from the nine transects without Cytisus scoparius (Table
1). Cover of Poa sieberiana ranged from 54-100\% for all transects without Cytisus scoparius. Empodisma minus (up to $65 \%$ ) and Tetrarrhena turfosa (up to $68 \%$ ) (Figure 2) were also common. Other species are less frequent; 36 species had less than $1 \%$ groundcover.

In comparison transects with Cytisus scoparius had few other species present, and groundcover was dominated by Poa sieberiana ( $83 \%$ cover) (Table 2). At the time of measuring cover in these transects herbicide treatment 2 months earlier appeared to have killed most of the standing Cytisus scoparius but there were a small number of Cytisus scoparius seedlings present and a few Cytisus scoparius branches had not died. A total of 14 native species (and 1 exotic in addition to Cytisus scoparius) were recorded from the nine transects with Cytisus scoparius. Only the tall shrub Hakea microcarpa (1.4\%) and the grass Microlaena stipoides (1.5\%) had cover greater than $1 \%$. There was very little Tetrarrhena turfosa and no Empodisma minus recorded. Hakea microcarpa did not appear to be greatly affected by the Cytisus scoparius herbicide treatment.

The non-metric multidimensional scaling (NMDS) analysis produces an ordination diagram (see Figure 5) which is a graphical representation of the information in the distance matrix. Similarities between samples (i.e. transects) are indicated by the relative closeness of the plotted points on the ordination diagram. The stress associated with Figure 5 (i.e. 0.0887 ) indicates the configuration provides a good representation of the actual dissimilarities. The 2-dimensional

Table 2. Plant species cover in February 2008 in open plains transects with dense Cytisus scoparius infestation that had been treated with herbicide in December 2007, Edwards Plain, Barrington Tops National Park.

Genus / species (family (subfamily)) * = naturalised

*Cytisus scoparius (Fabaceae (Faboideae) - dead

*Cytisus scoparius - live

Poa sieberiana (Poaceae)

Microlaena stipoides var. stipoides (Poaceae)

Hakea microcarpa (Proteaceae)

Carex sp. (JRHosking 2585 et al.) (Cyperaceae)

Luzula densiflora or L. flaccida (Juncaceae)

Dichelachne inaequiglumis (Poaceae)

Anthosachne rectiseta (Poaceae)

Viola fuscoviolacea (Violaceae)

Tetrarrhena turfosa (Poaceae)

Gonocarpus humilis (Haloragaceae)

Hydrocotyle peduncularis (Araliaceae)

Rytidosperma penicillatum (Poaceae)

*Acetosella vulgaris (Polygonaceae)

Oreomyrrhis eriopoda (Apiaceae)

Wahlenbergia ceracea (Campanulaceae (Campanuloideae))

Number of species, including Cytisus scoparius

Average age (years) of older Cytisus scoparius plants based on growth ring counts (yr) of three shrubs in areas near transects Groundcover for live species

Groundcover for live species other than Poa sieberiana and

Cytisus scoparius

\section{Cover in transects $(\%)$} 86

0

94

2
90
0

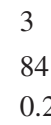

$\begin{array}{ll}3 & 4 \\ 84 & 88\end{array}$

4

$88 \quad 94$

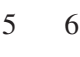

$\begin{array}{llll}0.2 & 0 & 23 & 3\end{array}$

90

7

8

9

$\begin{array}{lllllll}0.1 & 0.1 & 2.8 & 5.1 & 1.1 & 4.1 & 0.1\end{array}$

12.9

$\begin{array}{llll}0.2 & 1.7 & 0.8 & 0.8\end{array}$

0.1

\section{8}

0.5

$$
0.4
$$

0.2

$\begin{array}{ll}0.1 & 0.1\end{array}$

0.1

0.1

0.1

0.1

$\begin{array}{lllllllll}4 & 2 & 7 & 10 & 5 & 5 & 4 & 4 & 5\end{array}$

$\begin{array}{lllllllll}16 & 14 & 18 & 13 & 17 & 12 & 13 & 14 & 13\end{array}$

$\begin{array}{lllllllll}94 & 90 & 101 & 100 & 118 & 61 & 42 & 105 & 104\end{array}$

$\begin{array}{lllllllll}0.2 & 0 & 0.6 & 3.6 & 4 & 18.8 & 1.6 & 4.2 & 1.2\end{array}$
Total Cover (\%)

89.83

3.22

83.27

1.49

1.44

0.40

0.11

0.10

0.06

0.06

0.04

0.02

0.02

0.02

0.01

0.01

0.01 
solution to the NMDS analysis (Figure 5) shows each transect as a plotted point (Cytisus scoparius transects = 1A-9A, transects with no Cytisus scoparius $=1 \mathrm{~B}-9 \mathrm{~B})$. Similarities in species composition between transects is shown by their positions and the distances between those plotted points. Most of the Cytisus scoparius transects are clustered near the centre of the diagram, indicating a near uniform community structure whereas the transects with no Cytisus scoparius are more dispersed, indicating greater diversity of species.

Data on annual changes in groundcover abundance of species along a $20 \mathrm{~m}$ Cytisus scoparius infested line transect on Edwards Plain was available for the period 2003-2008 (Table 3, Figure 6). The transect was herbicide treated in December 2007 prior to the 2008 recording but decreases in the cover of native species in earlier years is presumably due to Cytisus scoparius competition/shading. This shows a marked decrease in groundcover for species other than
Cytisus scoparius and Poa sieberiana over the 5 year period (e.g. Oreomyrrhis eriopoda). In 2008 based on growth rings Cytisus scoparius plants ranged in age from 11 to 19 years of age with an average age of 14.5 years (Table 2) suggesting that shading impacts had probably been present for at least a decade. High levels of dead Cytisus scoparius groundcover prior to herbicide treatment were due to naturally occurring lower branch death.

\section{Comparison with flora in the study area in the 1930s}

Importantly while our study indicated high levels of Cytisus scoparius in the study area now, Fraser \& Vickery (1939) did not mention Cytisus scoparius as being present in this area, or in other areas of native vegetation on the Barrington Tops. This supports the Waterhouse (1988) evidence and indicates that the invasion of Cytisus scoparius has been relatively recent.

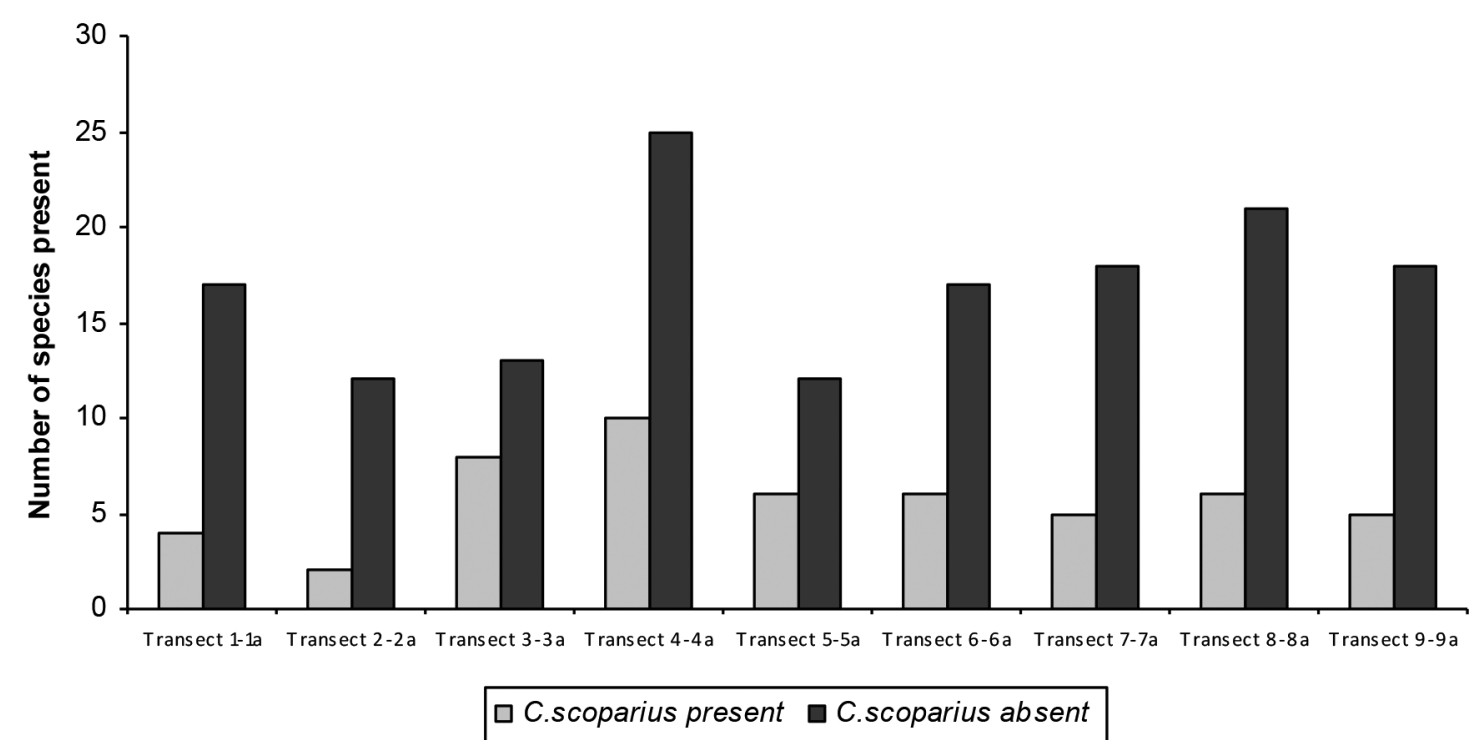

Fig. 3. A comparison of the number of species found in $10 \mathrm{~m}$ line transects in areas with and without Cytisus scoparius on Edwards Plain.

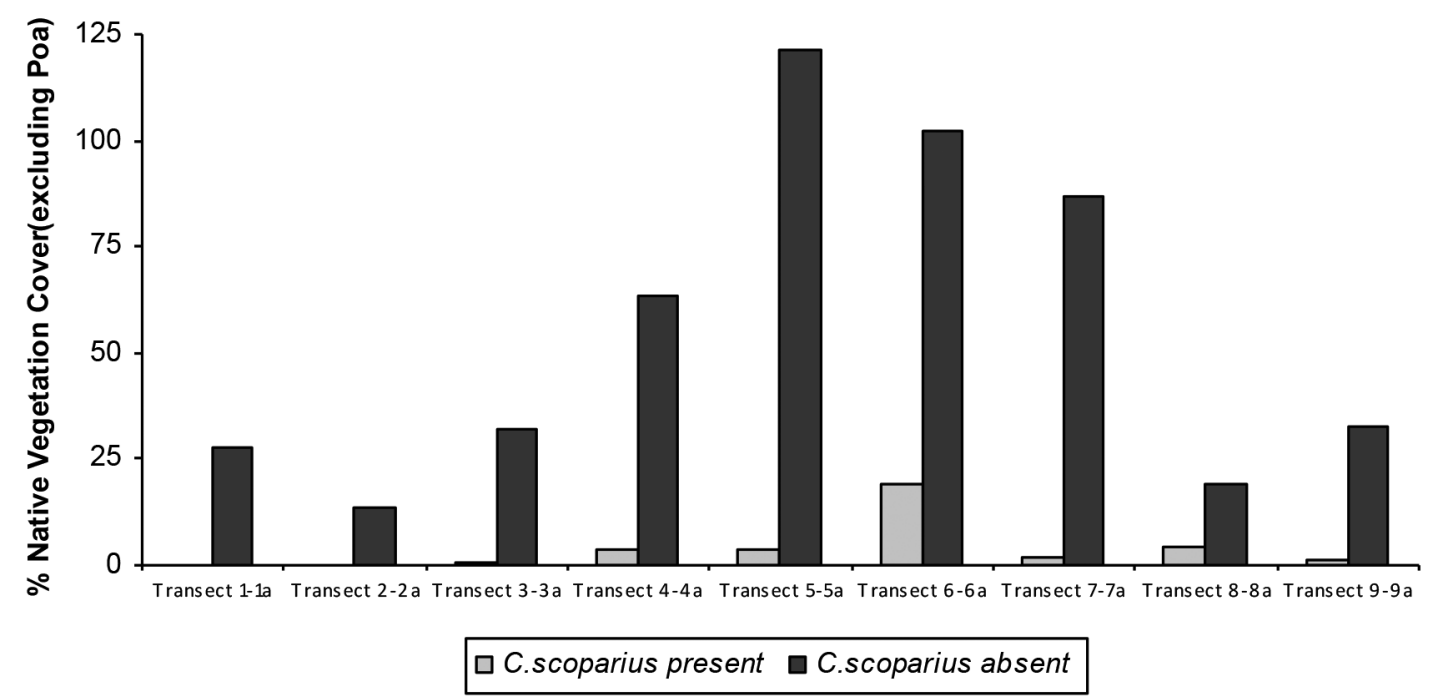

Fig. 4. A comparison of the area occupied by native vegetation in $10 \mathrm{~m}$ line transects in areas with and without Cytisus scoparius on Edwards Plain. Cover of Poa sieberiana is not included in the figure as it is common in areas with and without broom. 


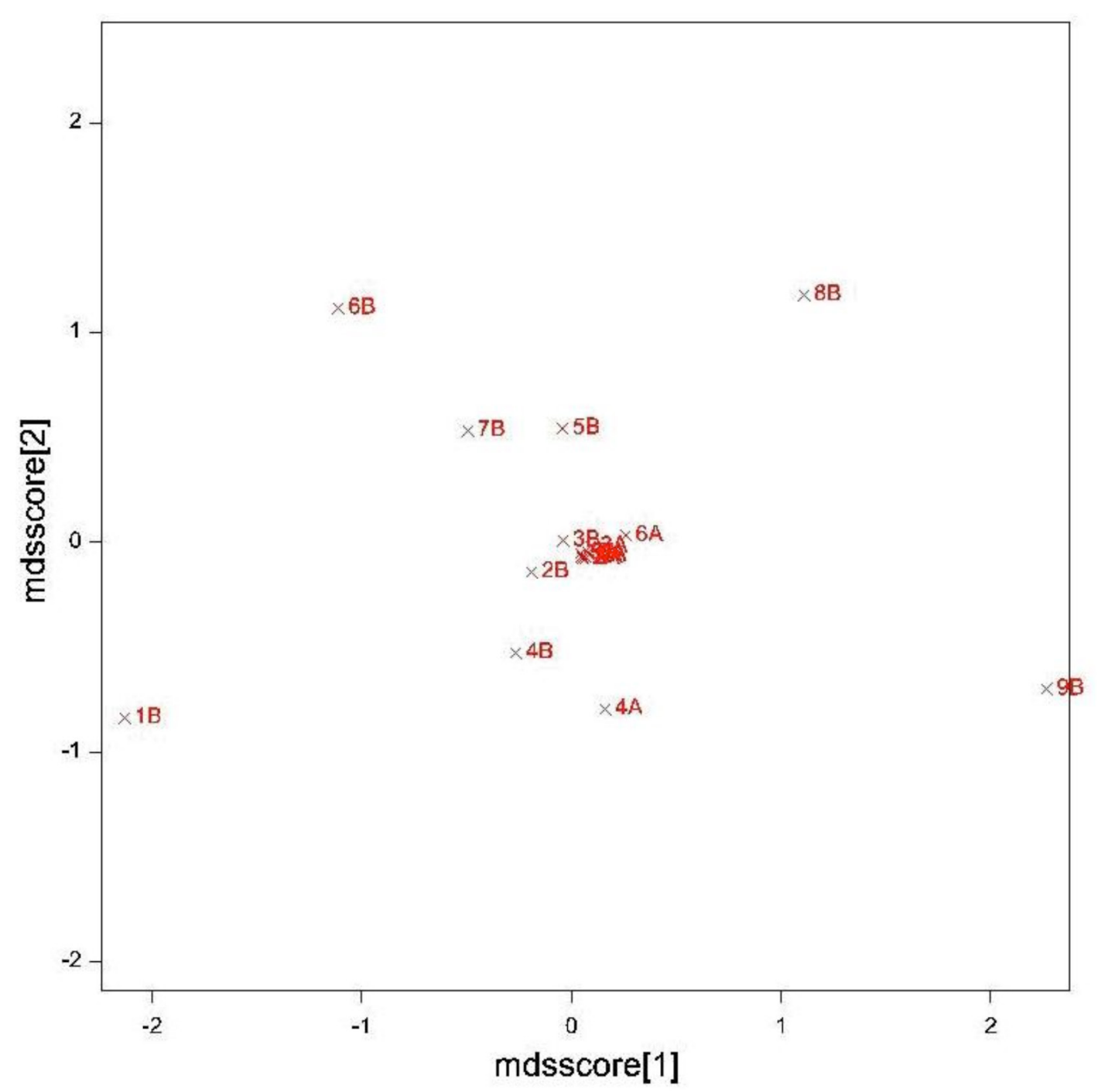

Fig. 5. Non-metric multidimensional scaling 2D solution (stress $=0.0887$ ) showing Cytisus scoparius $(\mathrm{A})$ and non-Cytisus scoparius $(\mathrm{B})$ transects (N.B. transect data used to create the Euclidean distance matrix excluded Cytisus scoparius). Similarities in species composition between transects is shown by their positions and the distances between these plotted points. Most of the Cytisus scoparius transects are clustered near the centre of the diagram, indicating a near uniform community structure for these transects.

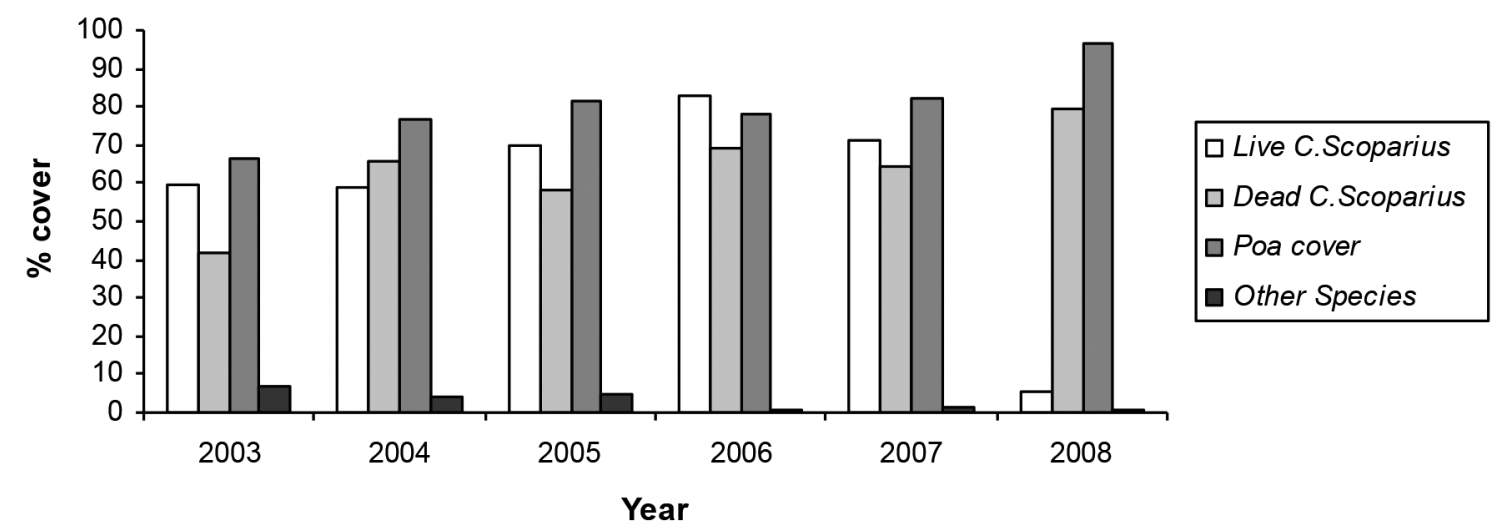

Fig. 6. Plant species present in a 20 metre line transect through Cytisus scoparius from 2003 to 2008 on Edwards Plain. 
A comparison of the species lists for this study (Tables 1 and 2) with that of Fraser \& Vickery (Table 4) shows that most of the species found in the earlier study can still be found in the area, though one very common species in treeless areas now, Tetrarrhena turfosa, surprisingly is not mentioned in their publication but was collected by Joyce Vickery in 1934 (at that time labelled Tetrarrhena juncea).

Some of the common species listed for this area in Fraser \& Vickery (1939) were not encountered in the nine paired transects on Edwards Plain. Lycopodium fastigiatum was listed as locally common by Fraser \& Vickery and is still present in the area, but was not encountered in the transects. Acrothamnus hookeri, Acacia barringtonensis, the exotic Lotus corniculatus, Persoonia acuminata and Pimelea linifolia subsp. linifolia, were not encountered in our study but are still known from other areas on the Barrington Tops. Recent collections and observations at various times of the year suggest the species referred to as Acrothamnus hookeri from frost-hollow areas is likely to be a rhizomatous taxon that does not form flowers. Acrothamnus hookeri that forms fruits and flowers is locally common in woodlands and open forest elsewhere on the Barrington Tops.
Fraser \& Vickery listed many orchid species as locally common but we could not determine the species present in our transects as they were not in flower, and above ground parts of some species may not have been present. Fraser \& Vickery found many more orchids in treeless areas; this is probably a result of the timing of their visits to the Barrington Tops relative to our February study. Based on dates of specimens that they collected they appear to have mainly been collecting in the area in January over a number of years. One orchid species, Diurus venosa, listed in Fraser \& Vickery (1939) as locally common is now listed as Vulnerable under the NSW Threatened Species Conservation Act 1995. This species is still present in the study area but the species is not obvious in February. It is common in many areas on the Barrington Tops.

The voucher specimen for Viola hederacea collected by Fraser \& Vickery has been redetermined as Viola fuscoviolacea (Figure 7). Both Viola hederacea and Viola fuscoviolacea are present on the Barrington Tops and were probably confused by Fraser \& Vickery (as they were by J.R. Hosking initially). They did however point out that the species found in the swamps (Viola fuscoviolacea now) has smaller flowers and

Table 3. Plant species cover along a 20 metre line transect through Cytisus scoparius recorded annually from 2003 to 2008. Cytisus scoparius herbicide treated in December 2007, Edwards Plain, Barrington Tops National Park.

Genus and species (family (subfamily) $) *=$ naturalised

*Cytisus scoparius - live (Fabaceae (Faboideae))

*Cytisus scoparius - dead (Fabaceae (Faboideae))

Poa sieberiana (Poaceae)

Hakea microcarpa (Proteaceae)

Carex sp. (JRHosking 2585 et al.) (Cyperaceae)

Oreomyrrhis eriopoda (Apiaceae)

*Cerastium vulgare (Caryophyllaceae)

Wahlenbergia ceracea (Campanulaceae (Campanuloideae))

Hydrocotyle peduncularis (Araliaceae)

Microlaena stipoides var. stipoides (Poaceae)

Gentianella barringtonensis (Gentianaceae)

*Hypochaeris radicata (Asteraceae)

Pratia peduncularis (Campanulaceae (Lobeloideae))

Luzula densiflora and/or L. flaccida (Juncaceae)

Scleranthus sp. (JRHosking 2489) (Caryophyllaceae)

Gonocarpus humilis (Haloragaceae)

Viola fuscoviolacea (Violaceae)

Carex sp. (JRHosking 2873) (Cyperaceae)

Dichelachne inaequiglumis (Poaceae)

Juncus sp. (Juncaceae)

Rytidosperma penicillatum (Poaceae)

Viola betonicifolia (Violaceae)

Epilobium billardierianum subsp. cinereum (Onagraceae)

Stellaria flaccida (Caryophyllaceae)

\section{Cover in transects (\%) from 2003 to 2008}

\begin{tabular}{|c|c|c|c|c|c|}
\hline 8.iv.2003 & 31.ii.2004 & 23.ii.2005 & 21.ii.2006 & 20.ii.2007 & 25.ii. 2008 \\
\hline 59 & 59 & 70 & 84 & 71 & 6 \\
\hline 42 & 66 & 58 & 69 & 65 & 80 \\
\hline \multirow[t]{3}{*}{65} & 77 & 81 & 78 & 82 & 96 \\
\hline & 2.1 & 2.5 & & & \\
\hline & 0.45 & 0.95 & 0.5 & 0.15 & 0.45 \\
\hline 2.3 & 0.05 & 0.1 & & & \\
\hline 1.8 & & 0.05 & & & \\
\hline 0.25 & 0.6 & 0.25 & 0.05 & 0.25 & \\
\hline 1 & 0.05 & & & & \\
\hline & & & 0.25 & 0.5 & \\
\hline
\end{tabular}

0.55

0.5

0.5 
Table 4. Species frequencies recorded by Fraser \& Vickery (1939) in subalpine grassland at the Barrington Tops, with updated nomenclature. Frequencies classes used were: Rare, Scanty, Frequent, Common, Locally Common and Very Common

\section{Order \& family \\ (subfamily),} current use

\author{
F
}

\& family in Fraser \&/o

$\begin{array}{ll}\text { (where different) } & \begin{array}{l}\text { voucher at NSW } \\ \text { or SYD (v) }\end{array}\end{array}$

$\begin{array}{ll}\text { (where different) } & \begin{array}{l}\text { voucher at } \\ \text { or SYD (v) }\end{array}\end{array}$
Genus and species, current use, $*$ naturalised

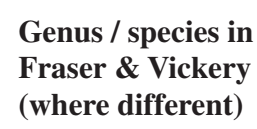

Fraser \& Vickery
(where different)

Frequency in

Fraser \&

Vickery

\section{Pteridophytes}

Lindsaeaceae

Lycopodiaceae

Polypodiaceae

Polypodiaceae

\section{Monocotyledons}

Asparagaceae Liliaceae

(Lomandroideae)

Cyperaceae

Juncaceae

Orchidaceae

Poaceae

Gramineae

Restionaceae

Dicotyledons

Araliaceae

Asteraceae
Umbelliferae

Compositae
Lindsaea linearis

Lycopodium fastigiatum

Microsorum pustulatum

subsp. pustulatum

Arthropodium milleflorum

Lomandra longifolia

Isolepis $\mathrm{sp}$.

Lepidosperma tortuosum

Schoenus apogon

Luzula meridionalis

Diuris venosa

Microtis rara?

Microtis unifolia

Prasophyllum brevilabre

Prasophyllum odoratum s.lat. \& Prasophyllum patens

Thelymitra ixioides

Deyeuxia gunnii

Poa sieberiana s.lat.

Empodisma minus

Hydrocotyle peduncularis

Craspedia canens \&

Craspedia variabilis

Lagenophora montana

\& Lagenophora stipitata

Solenogyne gunnii

Xerochrysum bracteatum with yellow involucral bracts

Xerochrysum bracteatum with white involucral bracts

Wahlenbergia ceracea

Pratia pedunculata

Scleranthus sp.

(same as JRHosking 2489)

Acrothamnus hookeri

Leucopogon pilifer

Hovea heterophylla

*Lotus corniculatus

Pultenaea fasciculata

Sphaerolobium minus

*Trifolium repens

Acacia barringtonensis

Scaevola hookeri
Lindsaya linearis

Lycopodium clavatum

var. fastigiatum

Pleopeltis diversifolia

Arthropodium paniculatum

Scirpus setaceus

Schoenus ericetorum

Luzula campestris

Microtis parviflora

Microtis porrifolia

Prasophyllum odoratum

Deyeuxia breviglumis

Poa caespitosa s.lat.

Hypolaena lateriflora

Hydrocotyle hirta

Craspedia Richea

Lagenophora Billardieri

Lagenophora emphysopus

Helichrysum lucidum

Helichrysum elatum

Wahlenbergia gracilis

Lobelia pedunculata

Scleranthus biflorus

Leucopogon Hookeri

Leucopogon collinus

(Mimosoideae)

Goodeniaceae
Leguminosae v

$\mathrm{v}$

$\begin{array}{ll} & \text { Scanty } \\ & \text { Common } \\ & \text { Locally Common } \\ \text { Sphaerolobium vimineum } & \begin{array}{l}\text { Scanty } \\ \text { Rare }\end{array} \\ \text { Acacia Clunies-Rossiae } & \text { Locally Common } \\ \text { Scaevola Hookeri } & \text { Locally Common }\end{array}$

Scanty

Locally common

Scanty

Common

Rare

Frequent

Frequent

Frequent

Frequent

Locally Common

Frequent

Frequent

Locally Common

Locally Common

Locally Common

Frequent to

Common

Very common

Frequent

Scanty

Common

Scanty

Locally Common

Locally Common

Common

Frequent

Frequent

Frequent

Common

Locally Common

Locally Common 
Order \& family Order \& family in Fraser \&/or (subfamily), current use
Genus and species, current use, $*$ naturalised

(where different) voucher at NSW

or SYD (v)
Genus / species in Fraser \& Vickery (where different)
Frequency in Fraser \&

Vickery

\begin{tabular}{|c|c|c|c|c|c|}
\hline Lamiaceae & Labiatae & $\mathrm{v}$ & Ajuga australis s.lat. & Ajuga australis & Frequent \\
\hline Loganiaceae & & $\mathrm{v}$ & Mitrasacme serpyllifolia & & Frequent \\
\hline Oenotheraceae & & $\mathrm{v}$ & $\begin{array}{l}\text { Epilobium billardierianum subsp. } \\
\text { cinereum }\end{array}$ & Epilobium glabellum & Scanty \\
\hline Orobanchaceae & Scrophulariaceae & $\mathrm{v}$ & Euphrasia ciliolata & Euphrasia Brownii & Scanty \\
\hline Plantaginaceae & & $\mathrm{v}$ & Plantago cladorophylla & Plantago varia & Scanty \\
\hline Polygalaceae & & $\mathrm{v}$ & Comesperma retusum & Comesperma sylvestre & Scanty \\
\hline \multirow[t]{2}{*}{ Proteaceae } & & $\mathrm{v}$ & Hakea microcarpa & & Locally Common \\
\hline & & $\mathrm{v}$ & Persoonia acuminata & Persoonia oxycoccoides & Locally Common \\
\hline Ranunculaceae & & $\mathrm{v}$ & Ranunculus lappaceus & & Very Common \\
\hline Santalaceae & & $\mathrm{v}$ & Exocarpos nanus & Exocarpus nana & Scanty \\
\hline Stylidiaceae & Candolleaceae & $\mathrm{v}$ & Stylidium graminifolium & Candollea serrulata & Common \\
\hline Thymelaeaceae & & $\mathrm{v}$ & Pimelea linifolia subsp. linifolia & Pimelea linifolia & Locally Common \\
\hline \multirow[t]{2}{*}{ Violaceae } & & $\mathrm{v}$ & Viola betonicifolia & & Scanty \\
\hline & & $\mathrm{v}$ & Viola fuscoviolacea & Viola hederacea & Scanty \\
\hline
\end{tabular}

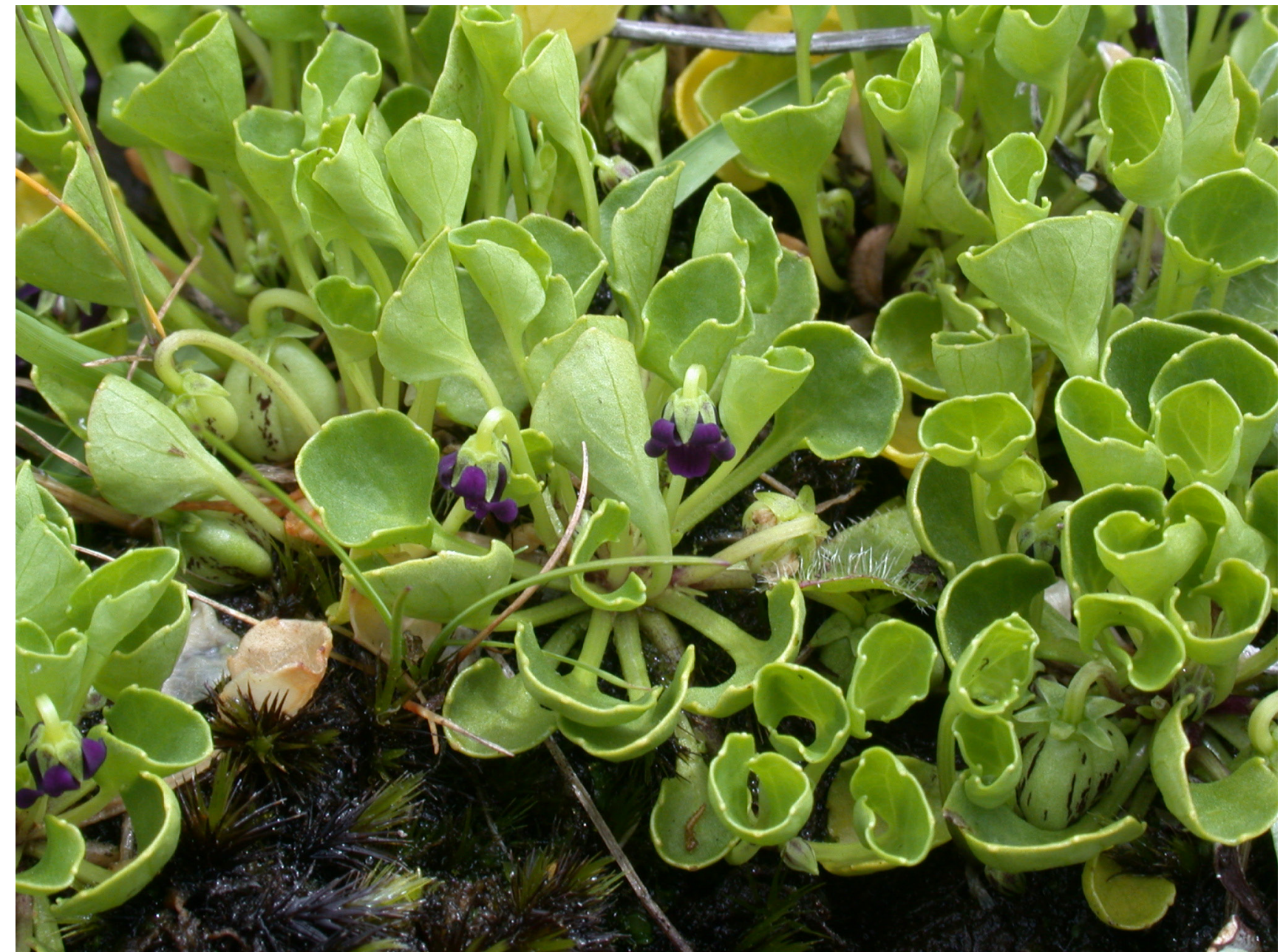

Fig. 7. Viola fuscoviolacea, a species found in treeless frost hollow vegetation, that was at one time included in Viola hederacea s.lat. 
leaves than the form found in other areas (Viola hederacea now). Viola fuscoviolacea is not only common in swamps but is also locally common in frost-hollow areas on the Barrington Tops. There is uncertainty regarding the identity of species referred to as Xerochrysum lucidum by Fraser \& Vickery; this specimen could not be located at the National Herbarium of NSW.

Fraser \& Vickery did not note a few of the species common now, particularly Carex sp. (collection J.R.Hosking 2585 et $a l$.), an unnamed species that has been mistaken for Carex appressa in the past. Carex appressa, a different taxon, is present alongside watercourses in the area. Nor did they mention many Poaceae species; these are much more obvious when inflorescences are present and would not have been obvious if collections were made in January or earlier in the Australian summer.

One species found in this study, Euphrasia ciliolata, is listed as vulnerable on the NSW Threatened Species Conservation Act 1995; it is still reasonably common in this area and in other areas on the Barrington Tops. Numbers appear to vary considerably from year to year.

\section{Discussion}

Our results indicate that Cytisus scoparius is having a major competitive impact on native vegetation in naturally treeless frost-hollow vegetation communities on the Barrington Tops. These vegetation communities are of limited extent and significant in ecological and biogeographical terms. Disjunct patches of naturally treeless frost-hollow vegetation communities are found at higher altitudes along the Great Dividing Range in southern New South Wales and Victoria. For example a study on Nungar Plain vegetation, a treeless subalpine frost-hollow in Kosciuszko National Park (McDougall \& Walsh 2002) demonstrates the similarity in species. This similarity of high elevation vegetation was earlier pointed out by Fraser \& Vickery (1939), but a number of species thought to be the same in the past are now considered to be different, indicating the importance of conserving as many of the disjunct patches as possible. For example Gentianella barringtonensis was previously part of Gentiana diemesis (recorded in Fraser \& Vickery (1939) from a nearby area but not from subalpine grassland), a species complex that has subsequently been separated into a number of Gentianella species, and the Scleranthus species that was included in Scleranthus biflorus, is evidently a different unnamed taxon

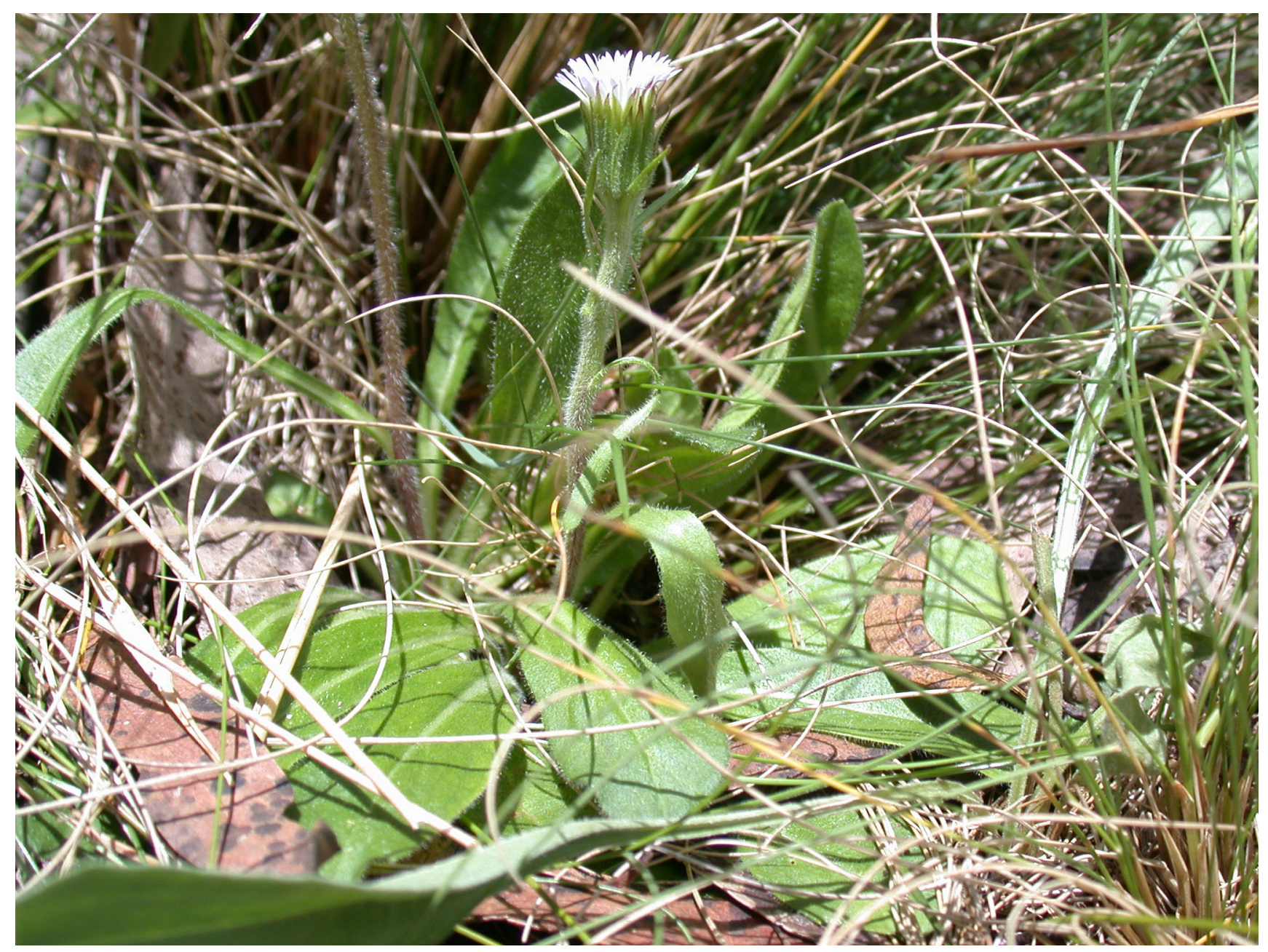

Fig. 8. Erigeron bellidioides, a species only recorded from treeless areas. 
(J. West pers. comm. 1995). Other species are likely to be different on further study as the Barrington Tops does not appear to have had high levels of taxonomic study in the past.

A number of the species recorded in this study have only been observed and collected in treeless areas though some of these are also found in swamps and alongside watercourses in treeless areas. All of these areas are impacted by Cytisus scoparius. Species only recorded from treeless areas include Tetrarrhena turfosa, Empodisma minus, Erigeron bellidioides (Figure 8), Leucopogon pilifer, Velleia montana Mitrasacme serpyllifolia and Xerochrysum bracteatum (form with leaves mainly in a basal rosette at flowering and with yellow involucral bracts - one of three or four forms of Xerochrysum bracteatum found on the Barrington Tops),

\section{Impact of Cytisus scoparius}

Only Poa sieberiana and Hakea microcarpa appear to survive at reasonable levels in dense Cytisus scoparius infestations. With the exception of Hakea microcarpa which never forms dense stands that would exclude light from lower vegetation these naturally treeless frost-hollow areas have little in the way of tall shrubs. The impact of Cytisus scoparius, although it loses its leaves in cooler months, is not surprising if you consider that most other plants in this area are not subject to dense shade over warmer months. Many of the plant species in this treeless vegetation community are not found in surrounding woodland vegetation communities despite these areas having an open forest canopy with high light penetration to the ground layer. Cytisus scoparius also adversely affects open forest areas without a native shrub and vine understorey (Waterhouse 1988, J.R. Hosking and M. Schroder unpubl.), but in areas where there is a native shrub and vine understorey Cytisus scoparius appears to have little impact on the native vegetation with Cytisus scoparius plants growing and dying without ever becoming a dominant species (J.R. Hosking and M. Schroder unpubl.).

Wearne \& Morgan (2004) reported a loss of native species or a reduction in their abundance associated with Cytisus scoparius invasion in a subalpine area in Victoria, in Eucalyptus pauciflora woodland with an open shrubby understorey. Such areas occur on the Barrington Tops but were not in our study area. Wearne \& Morgan (2006) also reported on seed rain in Cytisus scoparius stands compared with areas outside Cytisus scoparius stands. The seed rain showed significant decreases in species richness and seed density in areas that had been invaded for a long time. Our study was in a different type of vegetation community but did show a similar decrease in numbers and cover of native species. The impact of Cytisus scoparius on seed banks or seed rain of native species has not been determined in our study but the lack of native species would indicate that there is likely to be little in the way of native species seed rain in the area.

In India, in grasslands of the Nilgiri Hills, Cytisus scoparius at intermediate densities decreased abundance of light demanding species, and increased shade tolerant species from neighbouring areas (Srinivasan et al. 2007). Shade tolerant species can establish under Cytisus scoparius in woodlands elsewhere on the Barrington Tops (unpubl. data J.R. Hosking and M. Schroder) though these shade tolerant species do not survive in the colder conditions that occur in open grasslands compared with treed areas, or do not appear to have reached this area.

There are other studies where the impact of an invasive shrub species shows similar impacts on native vegetation. The impact of the South African shrub Chrysanthemoides monilifera subsp. rotundata bitou bush on native vegetation on the New South Wales coast was found to vary depending on the vegetation community where it occurred, with this species decreasing cover abundance of native grasses and herbs in fore dune sites that normally have little in the way of trees or shrubs (Mason \& French 2008). In fynbos vegetation in South Africa the Australian shrub Acacia saligna decreased species richness, cover and frequency much the same as Cytisus scoparius did in this study (Holmes \& Cowling 1997). In California Hobbs \& Mooney (1986) showed that invasion of grassland by the native shrub species, Baccharis pilularis subsp. consanguinea, significantly changed the abundance of herbaceous grassland species through reduction of light reaching the ground, and increased herbivory. Although not measured in our study, light was decreased in Cytisus scoparius stands, particularly when Cytisus scoparius was in leaf. Whether herbivory changes in, or at the edges of Cytisus scoparius stands on treeless plains on the Barrington Tops compared with more exposed grassland areas is not known. Even grasses taller than herbs in invaded communities can cause significant losses of herbaceous species e.g. for Imperata cylindrica invasion of longleaf pine (Pinus palustris) communities in southeastern Mississippi (Brewer 2008).

\section{Possible changes to management in this area}

Our results indicate that Cytisus scoparius has reduced the number and groundcover of species in the area compared with what is found in areas without Cytisus scoparius (Table 1), and control of Cytisus scoparius in this area is justified to prevent its further spread. However, we recommend that the control technique used must consider the potential impact to surrounding native vegetation communities. Where only individual Cytisus scoparius small plants are present these should be removed manually as this will have less impact on native vegetation than foliar applied herbicide. Where infestations are more dense (up to $40 \%$ cover) the cut and paint method using glyphosphate carefully applied to stems close to the ground is recommended. For dense stands where non target damage to surrounding vegetation communities can be avoided the first treatment is likely to be more cost efficient using foliar application of a recommended broad leaf herbicide. However follow-up seedling control should be limited to physical removal to encourage natural regeneration and limit off target damage.

The herbicide being used to control Cytisus scoparius is likely to impact on other species as was the case where (a different) herbicide was used to control bitou bush, Chrysanthemoides monilifera subsp. rotundata, in coastal New South Wales 
(Matarczyk et al. 2002, Mason \& French 2007, Mason et al. 2007). However, as Cytisus scoparius appears to be able to exclude most other species from densely infested areas attempts need to be made to limit its spread.

Our study found that exotic species, other than Cytisus scoparius, contributed little to ground cover in naturally treeless frost-hollow areas. In a similar area of frost-hollow grasslands in Kosciuszko National Park in southern New South Wales where Cytisus scoparius was not present, Godfree et al. (2004) found that exotic species contributed little to the cover of species in the area. Interestingly, the most common exotic species found by Godfree et al. (2004) were also recorded in our study, these being Hypochaeris radicata, Acetosella vulgaris, Trifolium repens and Cerastium vulgare. Removal of Cytisus scoparius from Edwards Plain and similar frost-hollow areas should not lead to an increase in any of the exotic species recorded from elsewhere in frosthollow areas.

There is no guarantee that areas from which Cytisus scoparius has been removed will recover diversity to levels of areas that have never had Cytisus scoparius. A single transect (near Transect 2 of Table 1- results not shown) from which Cytisus scoparius had been removed about two years previously was still dominated by Poa sieberiana (89\% ground cover) with a small amount of cover of a few other species (0.5\% Oreomyrrhis eriopoda, $0.1 \%$ Arthropodium milleflorum and $0.4 \%$ Cytisus scoparius). One transect is insufficient to draw conclusions from but it does suggest that recovery of species diversity and cover may not be rapid. Acacia saligna invasion of fynbos vegetation in South Africa significantly reduced seed bank diversity and richness of native species (Holmes 2002). This may also be the case in frost hollow vegetation at the Barrington Tops.

\section{Acknowledgements.}

We would like to acknowledge the assistance of Ruth Armstrong with data collection and Geoffrey James for Figure 1. Staff at the National Herbarium of New South Wales (NSW), Australian National Herbarium (CANB), South Australian Herbarium (AD) and Jeremy Bruhl from the herbarium in Armidale (NE) assisted with identification of some of the species found at the Barrington Tops. Maintenance of voucher specimens at NSW, CANB, MEL and $\mathrm{NE}$ is acknowledged as names for a number of the species listed are likely to change as a number of the names are based on high (for Australia) altitude species that occur in southern New South Wales and Victoria and those at the Barrington Tops may prove to be different. The manuscript was improved following suggestions from Royce Holtkamp, Andy Sheppard, Richard Groves, Paul Downey, an unnamed referee and Doug Benson.

\section{References}

Brewer, S. (2008) Declines in plant species richness and endemic plant species in longleaf pine savannas invaded by Imperata cylindrica. Biological Invasions 10: 1257-1264.

CMPS \& F Environmental (1995) Gloucester and Chichester Management Areas Environmental Impact Statement, Supporting Document 2: Hydrology and Water Quality. State Forests of New South Wales.

DECC [Department of Environment and Climate Change] (2008) Invasion and establishment of Scotch Broom - key threatening process declaration. http://www.environment.nsw.gov.au/ determinations/ScotchBroomKtp.htm

DECC [Department of Environment and Climate Change] (2010) Barrington Tops National Park, Mount Royal National Park, and Barrington Tops State Conservation Area plan of management, DECC, Sydney, NSW, http://www.environment.nsw.gov.au/ resources/planmanagement/final/20100833BarringtonMtRoyal Final.pdf (viewed 14 August 2013).

Downey, P.O. \& Smith, J.M.B. (2000) Demography of the invasive shrub Scotch broom (Cytisus scoparius) at Barrington Tops, New South Wales: insights for management. Austral Ecology 25: 477-485.

Fasham, M.J.R.(1977)A comparison of nonmetric multidimensional scaling, principal components and reciprocal averaging for the ordination of simulated coenoclines and coenoplanes. Ecology 58: 551-561.

Fogarty, G. \& Facelli, J.M. (1999) Growth and competition of Cytisus scoparius, an invasive shrub, and Australian native shrubs. Plant Ecology 144: 27-35.

Fraser, L. \& Vickery, J.W. (1939) The ecology of the upper Williams River and Barrington Tops districts. III. The eucalypt forests, and general discussion. Proceedings of the Linnean Society of New South Wales 64: 1-33.

Godfree, R., Lepschi, B. \& Mallinson, D. (2004) Ecological filtering of exotic plants in an Australian sub-alpine environment. Journal of Vegetation Science 15: 227-236.

Heinrich, A. \& Dowling, B. (2000) Threats to the rare and threatened plant species of Barrington Tops. Plant Protection Quarterly 15: 172-176.

Hobbs, R.J. \& Mooney, H.A. (1986) Community changes following shrub invasion of grassland. Oecologia 70: 508-513.

Holmes, P.M. (2002) Depth distribution and composition of seedbanks in alien-invaded and uninvaded fynbos vegetation. Austral Ecology 27: 110-120.

Holmes, P.M. \& Cowling, R.M. (1997) The effect of invasion by Acacia saligna on the guild structure and regeneration capabilities of South African fynbos shrublands. Journal of Applied Ecology 34: 317-332.

Holmgren, P.K., Holmgren, N.H. \& Barnett, L.C. (1990) Index herbariorum Part 1: the herbaria of the world. 8th Edition (New York Botanical Gardens: Bronx, New York).

Hosking, J.R., Smith, J.M.B. \& Sheppard, A.W. (1998) Cytisus scoparius (L.) Link ssp. scoparius. In Panetta, F.D., Groves, R.H. \& Shepherd, R.C.H. (Eds) The Biology of Australian Weeds. Volume 2, pp. 77-88 (R.G. \& F.J. Richardson: Melbourne).

Iwatsuki K., Boufford D.E. \& Ohba H. (Eds) (2001) Flora of Japan 2b (Kodansha: Tokyo).

McDougall, K.L. \& Walsh, N.G. (2002) The flora of the Nungar Plain, a treeless sub-alpine frost hollow in Kosciuszko National Park. Cunninghamia 7: 601-610.

Mason, T.J. \& French, K. (2007) Management regimes for a plant invader differentially impact resident communities. Biological Conservation 136: 246-259.

Mason, T.J. \& French, K. (2008) Impacts of a woody invader vary in different vegetation communities. Diversity and Distributions 14: 829-838. 
Mason, T.J., French, K. \& Russell, K.G. (2007) Moderate impacts of plant invasion and management regimes in coastal hind dune seed banks. Biological Conservation 134: 428-439.

Matarczyk, J.A., Willis, A.J., Vranjic, J.A. \& Ash, J.E. (2002) Herbicides, weeds and endangered species: management of bitou bush (Chrysanthemoides monilifera ssp. rotundata) with glyphosate and impacts on the endangered shrub, Pimelea spicata. Biological Conservation 108: 133-141.

Mooney, H.A. \& Hobbs, R.J. (Eds) (2000) Invasive species in a changing world (Island Press: Washington, D.C.).

Odom, D., Griffith, G.R., Schroder, M. \& Sinden, J.A. (2003) Using aerial mapping to analyse factors affecting the spread of Scotch broom. Plant Protection Quarterly 18: 6-10.

OEH [Office of Environment and Heritage] (2011) Hunter Region, Draft Regional Pest Strategy, Part B 2012-2015. OEH, Sydney, NSW, http://www.environment.nsw.gov.au/resources/pestsweeds /110892draftHunterRPMS.pdf (viewed 14 August 2013)

Parsons, W.T. \& Cuthbertson, E.G. (1992) Noxious weeds of Australia (Inkata Press: Melbourne).

Paynter, Q., Downey, P.O. \& Sheppard, A.W. (2003) Age structure and growth of the woody legume weed Cytisus scoparius in native and exotic habitats: implications for control. Journal of Applied Ecology 40: 470-480.

Prentice, I.C. (1977) Non-metric ordination methods in ecology. Journal of Ecology 65: 85-94.

Schroder, M. \& Howard, C. (2000) Controlling broom (Cytisus scoparius (L.) Link) in natural ecosystems in Barrington Tops National Park. Plant Protection Quarterly 15: 169-172.

Sheppard, A.W. \& Hosking, J.R. (Eds) (2000) Broom management. Proceedings of a workshop held at Ellerston and Moonan on 16-17 November 1998. Plant Protection Quarterly 15: 133-186.

Sheppard, A.W., Hodge, P., Paynter, Q. \& Rees, M. (2002) Factors affecting invasion and persistence of broom Cytisus scoparius in Australia. Journal of Applied Ecology 39: 721-734.

Srinivasan, M.P., Shenoy, K. \& Gleeson, S.K. (2007) Population structure of Scotch broom (Cytisus scoparius) and its invasion impacts on the resident plant community in the grasslands of Nilgiris, India. Current Science 93: 1108-1113.

Stokes, K.E., Buckley, Y.M. \& Sheppard, A.W. (2006) A modelling approach to estimate the effect of exotic pollinators on exotic weed population dynamics: bumblebees and broom in Australia. Diversity and Distributions 12: 593-600.

Waterhouse, B.M. (1988) Broom (Cytisus scoparius) at Barrington Tops, New South Wales. Australian Geographical Studies 26 239-248.

Wearne, L.J. \& Morgan, J.W. (2004) Community-level changes in Australian subalpine vegetation following invasion by the nonnative shrub Cytisus scoparius. Journal of Vegetation Science 15: 595-604.

Wearne, L.J. \& Morgan, J.W. (2006) Shrub invasion into subalpine vegetation: implications for restoration of the native ecosystem. Plant Ecology 183: 361-376.

Zuloaga, F.O. \& Morrone, O. (1999) Catálogo de las plantas vasculares de la República Argentina II. FabaceaeZygophyllaceae (Dicotyledoneae). Monographs in Systematic Botany 74 (Missouri Botanical Garden Press: St Louis).

Manuscript accepted 23 October 2013 